Institute of $\mathbf{F}_{\text {ood and }} \mathbf{A}_{\text {gricultural }} \mathbf{S}_{\text {ciences }}$

\title{
Ladybirds, Ladybird beetles, Lady Beetles, Ladybugs of Florida, Coleoptera: Coccinellidae ${ }^{1}$
}

\author{
J. H. Frank R. F. Mizell, III
}

\section{Introduction}

Ladybird is a name that has been used in England for more than 600 years for the European beetle Coccinella septempunctata. As knowledge about insects increased, the name became extended to all its relatives, members of the beetle family Coccinellidae. Of course these insects are not birds, but butterflies are not flies, nor are dragonflies, stoneflies, mayflies, and fireflies, which all are true common names in folklore, not invented names. The lady for whom they were named was "the Virgin Mary," and common names in other European languages have the same association (the German name Marienkafer translates to "Marybeetle" or ladybeetle). Prose and poetry mention ladybird, perhaps the most familiar in English being the children's rhyme:

Ladybird, ladybird, fly away home,

Your house is on fire, your children all gone...

In the USA, the name ladybird was popularly americanized to ladybug, although these insects are beetles (Coleoptera), not bugs (Hemiptera).

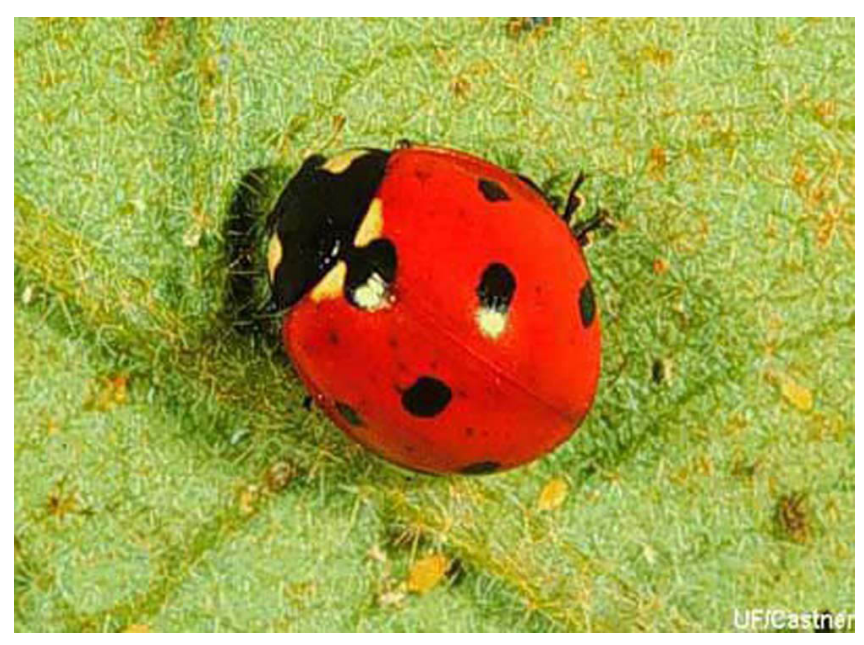

Figure 1. Adult Coccinella septempunctata Linnaeus, the sevenspotted lady beetle. Credits: James Castner, University of Florida

Now, the word ladybird applies to a whole family of beetles, Coccinellidae or ladybirds, not just Coccinella septempunctata. We can but hope that newspaper writers will desist from generalizing them all as "the ladybird" and thus deluding the public into believing that there is only one species. There are many species of ladybirds, just as there are of birds, and the word "variety" (frequently use by newspaper

1. This document is EENY-170, one of a series of Featured Creatures from the Entomology and Nematology Department, Florida Cooperative Extension Service, Institute of Food and Agricultural Sciences, University of Florida. Published: November 2000. Revised: April 2002. This document is also available on Featured Creatures Website at http://creatures.ifas.ufl.edu. Please visit the EDIS Website at http://edis.ifas.ufl.edu. Additional information on these organisms, including many color photographs, is available at the Entomology and Nematology Department website at http://entnemdept.ifas.ufl.edu/.

2. J. H. Frank, professor, Entomology and Nematology Department, University of Florida, Gainesville, FL, and R. F. Mizell, III, professor, Entomology and Nematology Department, NFREC, Monticello, FL.

The Institute of Food and Agricultural Sciences is an equal opportunity/affirmative action employer authorized to provide research, educational information and other services only to individuals and institutions that function without regard to race, color, sex, age, handicap, or national origin. For information on obtaining other extension publications, contact your county Cooperative Extension Service office. Florida Cooperative Extension Service/Institute of Food and Agricultural Sciences/University of Florida/Christine Taylor Waddill, Dean. 
writers) is not an appropriate substitute for the word "species." Many ladybird species are considered beneficial to humans because they eat phytophagous insects ("pests of plants," sometimes called "plant pests"), but not all eat pests of plants, and a few are themselves pests.

\section{Description}

Coccinellidae are a family of beetles belonging to the superfamily Cucujoidea, which in turn belongs to the series Cucujiformia within the suborder Polyphaga of the beetles (Coleoptera). Their relatives within the Cucujoidea are the Endomychidae ("handsome fungus beetles") and Corylophidae ("minute fungus beetles"). Worldwide, some 4500 species of ladybirds are known, of which 96 are currently reported to occur in Florida (Table 1). Some of these 96 are considered to be native, and others to be adventive ("having arrived from somewhere else and established feral populations"). Among the adventive species, some were introduced (introduced deliberately), and others are immigrants (having arrived by any means except deliberate introduction) (Frank \& McCoy 1990).

Ladybird adults are oval, range in length from about $1 \mathrm{~mm}$ to over $10 \mathrm{~mm}$ depending upon species, and have wings. Females on average are larger than males. Adults of some species are brightly colored. Their mandibles are used for chewing. Adult ladybirds are able to reflex-bleed from the tibio-femoral articulations (leg joints). The blood (hemolymph) is repellent by having a repulsive smell as well as containing (in some species) various alkaloid toxins (adaline, coccinelline, exochomine, hippodamine, etc.). The hemolymph is yellow and its repellency and toxicity are believed to be a defense mechanism against predators. Some people have claimed that the bright (red on black, or black on red) colors of some adult ladybirds are aposematic, which is to say that the colors warn would-be predators that the beetles are distasteful or toxic.

The immature stages (eggs, larvae, and pupae) also contain the toxins that their adults have, and in this characteristic, they resemble rove beetles (Staphylinidae) of the genus Paederus (Frank and Kanamitsu 1987) although the toxins are totally different. Toxins are said to be produced by dorsal glands in the larvae (Dixon 2000). Eggs are elongate-ovoidal, and in just a few species are protected by secretions of the adult female. Cannibalism of eggs, larvae and pupae is common, especially when prey is scarce. Larvae are mobile, and in some species (for example of Scymnus and Cryptolaemus) are protected by waxy secretions. Pupae are unprotected by a cocoon (as in some other beetles) but larvae may wander some distance from feeding sites (where they may be at risk from cannibalism) before pupating.

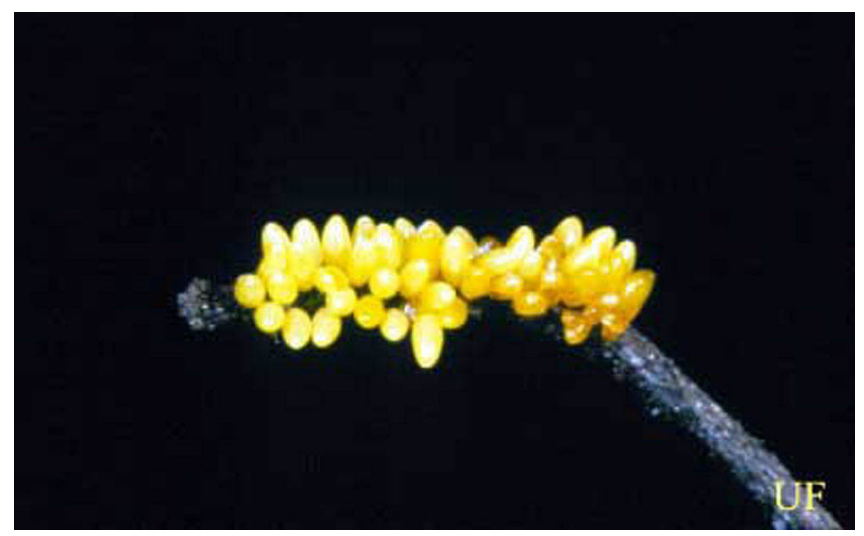

Figure 2. Lady beetle eggs. Credits: Russell F. Mizell, University of Florida

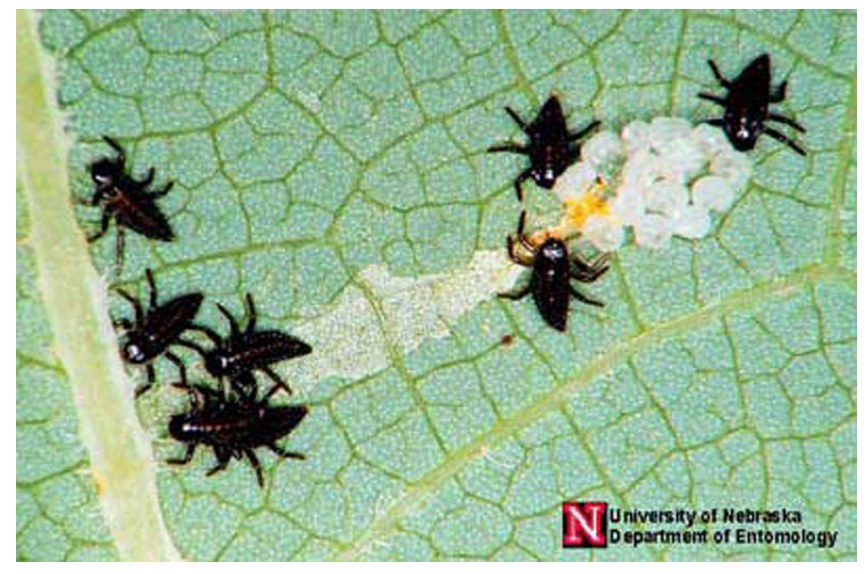

Figure 3. Newly hatched lady beetle larvae. Credits: Jim Kalisch, University of Nebraska - Lincoln (http://entomology.unl.edu/)

\section{Life Cycle and Behavior}

Ladybird eggs produce larvae that undergo four instars before pupating, metamorphosing, and giving rise to adults. So far as is known, all the Florida species have this typical life cycle. Typically, ladybirds have several generations each year, and 


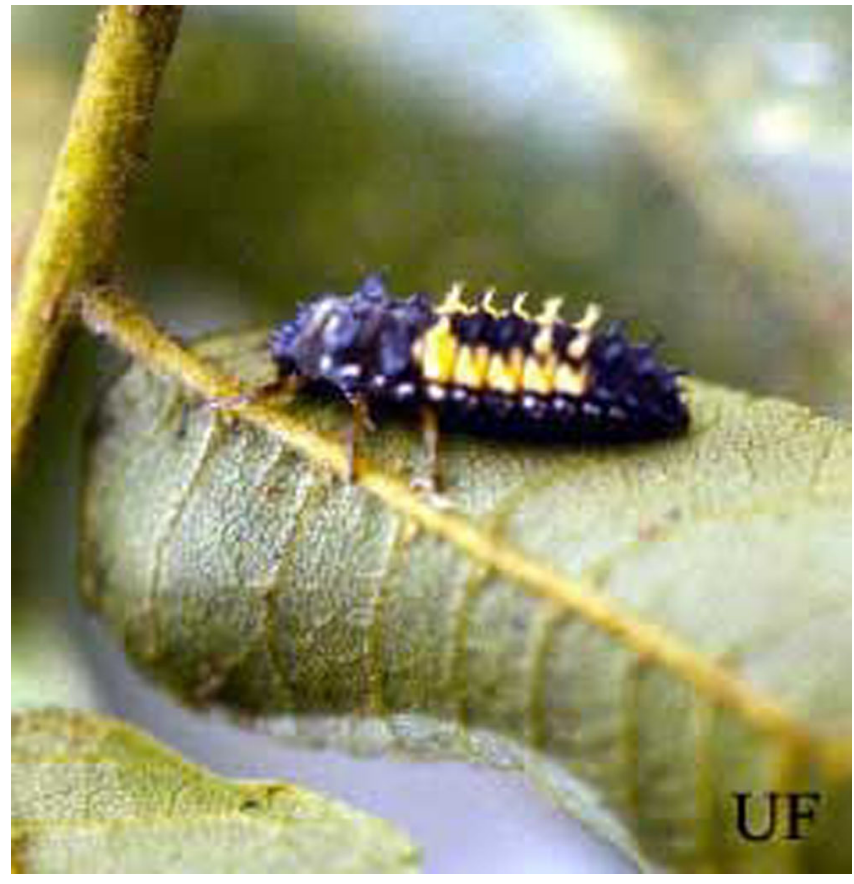

Figure 4. Larva of Harmonia sp., a lady beetle. Credits: Russell F. Mizell, University of Florida

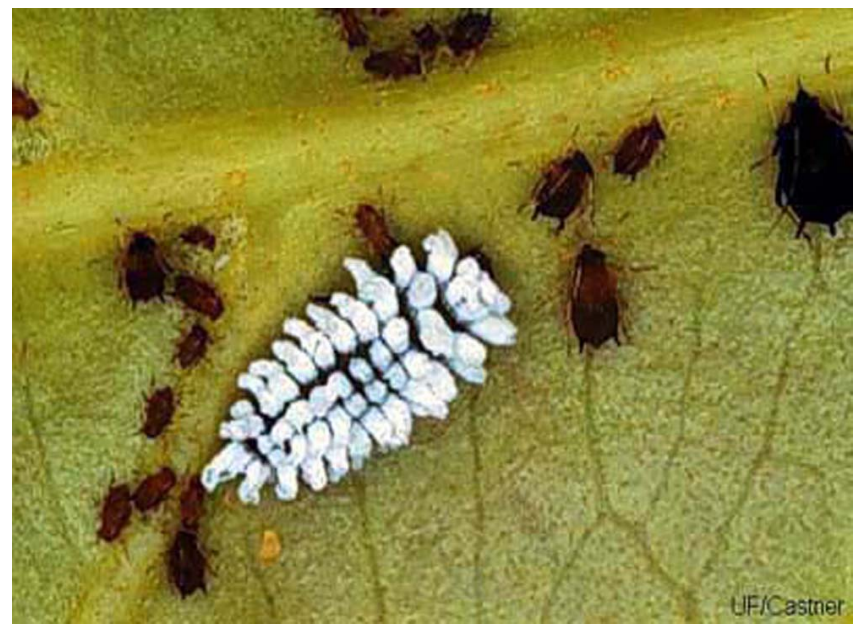

Figure 5. Larva of Scymnus sp., a lady beetle. Credits: James Castner, University of Florida

reproduction is slowed or halted by cooler winter weather, when adults may hibernate.

In Florida, adults and larvae of 75 species feed on scale insects (in the broad sense, see below), and only 13 feed primarily on aphids. As pointed out by Dixon (2000), there are typical differences in behavior between these trophic groups. Those that feed on aphids develop faster, age faster, move faster, typically are larger, and lay their eggs in clusters. Those that feed on scale insects develop more slowly, live longer, move more slowly, typically are smaller, and lay their eggs singly.

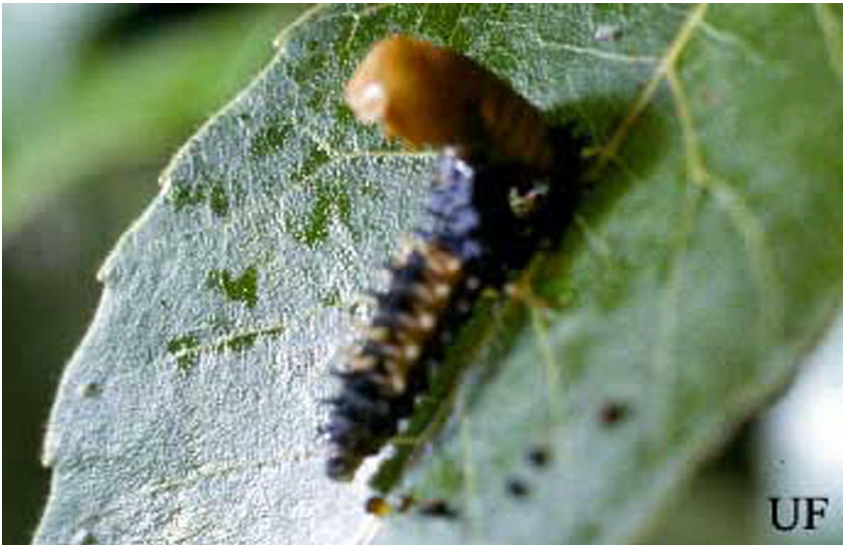

Figure 6. Larva of Harmonia sp., exhibiting cannibalism by feeding on a lady beetle pupa. Credits: Russell F. Mizell, University of Florida

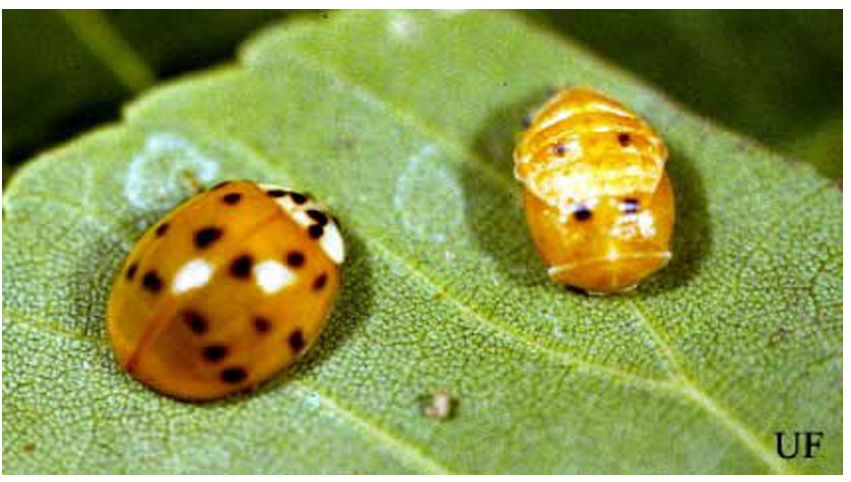

Figure 7. Adult and pupa of Harmonia sp., a lady beetle. Credits: Russell F. Mizell, University of Florida

\section{Food}

\section{(a) Plant Species - Feeding on Plants}

Adults and larvae of the subfamily Epilachninae feed on plants. In Florida, this subfamily is represented only by Epilachna borealis (Fabricius) and E. varivestis Mulsant. Epilachna borealis, the squash beetle, feeds on members of the squash family (Cucurbitaceae), and in Florida is restricted to the north, with a wide distribution in other states of the eastern USA. Epilachna varivestis, the Mexican bean beetle, feeds on members of the bean family (Leguminosae), and rarely has been found south of northern Florida. It is native to southern Mexico, but it is an immigrant to the USA, first detected in the west in 1849, and in northern Florida in 1930. Now, its distribution is from Costa Rica north through Mexico to the Rocky Mountain states of the USA, and with a separated eastern population (which extends southward to northern Florida). In Florida it can be controlled efficiently by releases of the 
parasitoid wasp Pediobius foveolatus (Crawford)

(Eulophidae) (Nong and Bennett 1994), which have to be made annually in the northeastern USA (Stevens et al. 1975) because of the more severe climate. It was discussed by Sanchez-Arroyo (1997).

\section{(b) Innocuous Species - Feeding on Mildews}

Ladybirds of the tribe Halyziini (of the subfamily Coccinellinae) feed on fungal growths (mildews) on the leaves of plants. In Florida, this tribe is represented only by the West Indian Psyllobora nana Mulsant which has invaded the extreme south of Florida, and by the widespread Psyllobora parvinotata Casey which also occupies coastal areas as far west as Louisiana.

\section{(c) Predatory Species - Feeding on Mites}

Adults and larvae of the tribe Stethorini (of the subfamily Scymninae) feed on tetranychid mites. In Florida, this tribe is represented only by Stethorus utilis (Horn), a tiny ladybird which is also distributed in the coastal plains of the southeastern states from North Carolina through Texas.

\section{(d) Predatory Species - Feeding on Whiteflies}

Three of Florida's ladybirds appear to be more or less specialized predators of whiteflies. They are Delphastus pallidus (LeConte) and D. pusillus (LeConte) (tribe Serangiini), and Nephaspis oculatus (Blatchley) (tribe Scymnini). The first two are considered native, and the third may be an immigrant from Central America. After Delphastus pusillus was found in Florida to be a very useful biological control agent against sweetpotato whitefly (Bemisia tabaci (Gennadius) (Hoelmer et al. 1993) including the "form" that later was called silverleaf whitefly (Bemisia argentifolii Bellows and Perring), it was made available commercially and used in other parts of the USA. Prey records for Nephaspis oculatus include Bemisia argentifolii (Liu et al. 1997) and Aleurodicus dispersus Russell (spiralling whitefly) and Aleurodicus cocois (Curtis).

\section{(e) Predatory Species - Feeding on Cottonycushion Scale}

Cottonycushion scale (Icerya purchasi Maskell), native to Australia, belongs to the homopterous family Margarodidae (commonly called "ground pearls," although this name hardly fits this species) in the superfamily Coccoidea (scale insects). It is a major pest of citrus, and an important pest of several other trees and shrubs including Acacia, Casuarina, and Pittosporum. After its arrival in California, presumably as a contaminant of imported plants, it threatened to ruin California's citrus industry in the late 1800s. It was controlled by importation, release, and establishment (as classical biological control agents) of Rodolia cardinalis (Mulsant) and a parasitoid fly, Cryptochetum iceryae (Williston). When cottonycushion scale became a problem in Florida, the same two biological control agents were imported from California into Florida. $R$. cardinalis is a highly effective control agent for cottonycushion scale.

\section{(f) Predatory Species - Feeding on Mealybugs}

Mealybugs are the homopterous family Pseudococcidae, which includes some notable pests of plants. The most notable ladybird predator of mealybugs in Florida is Cryptolaemus montrouzieri Mulsant, a species native to Australia, introduced into California first in 1891, and some time later from California into Florida. It has been marketed commercially as a control agent for mealybugs and is often effective, but has one unfortunate characteristic: its larvae produce waxy filaments making them look to the uninitiated like their mealybug prey. Many owners of plants have sprayed the larvae with chemicals in the mistaken belief that they are pests. This misidentification must be overcome by education. Cryptolaemus montrouzieri does not confine its attentions to mealybugs, and also eats soft scales (Coccidae) and armored scales (Diaspididae). Such a catholic diet is normal for a long list of Florida ladybirds, so that their diet cannot neatly be pigeonholed as armored scales or soft scales or mealybugs -- they may eat some prey in all of these families, and a few of the larger ones may even eat an aphid from time to time. For that reason, many 
genera and species are placed below under Feeding on Scale Insects.

\section{(g) Predatory Species - Feeding on Armored Scale Insects}

Eight species in four genera seem to feed largely or entirely on armored scale insects (Diaspididae). They include Microweisea coccidivora (Ashmead), M. misella (LeConte), and M. ovalis (LeConte) of the tribe Microweiseini, Zilus horni Gordon, Z. eleutherae Casey, Z. subtropicus (Casey) and perhaps Zagloba bicolor (Casey) (its diet is a guess) of the tribe Scymnillini, and Cryptognatha nodiceps Marshall of the tribe Cryptognathini. One of these, Cryptognatha nodiceps, is not native, having been imported in the 1930s, released, and established as a classical biological control agent for coconut scale (Aspidiotus destructor Signoret) (Frank and McCoy 1993).

\section{(h) Predatory Species - Feeding on Scale Insects}

Thirteen genera containing 65 species are placed here into this large trophic group that has scale insects as its prey, meaning members of the superfamily Coccoidea (the scale insects). This superfamily includes various related families, notably Coccidae (soft scales), Diaspididae (armored scales), Pseudococcidae (mealybugs), Dactylopiidae (cochineal scales), Kermesidae (gall-like scales), Eriococcidae (felt scales), Cerococcidae (ornate pit scales), and Asterolecaniidae (pit scales). The ladybird genera are named below, each followed by a number in parentheses, representing the number of species known from Florida: Decadomius (1), Diomus (9), Nephus (3), and Scymnus (16) (all in tribe Scymnini), Brachiacantha (7), Hyperaspidius (5), and Hyperaspis (16) (all in tribe Hyperaspini), Axion (1), Chilocorus (2), Curinus (1), and Exochomus (2) (all in tribe Chilocorini), Rhyzobius (1) (tribe Coccidulini), and Azya (1) (tribe Azyini) (see Table 1). It is not yet clear how, or whether, they divide up the scale insects between them, because reliable prey records are too incomplete. However, there is at least some level of prey specialization in these (and groups (e), (f), and (g) above) that feed on scale insects, which seems not to be the case for the next-discussed trophic group (those that feed on aphids). Brachiacantha has a curious life history in that its larvae so far as is known feed on scale insects within ant nests.

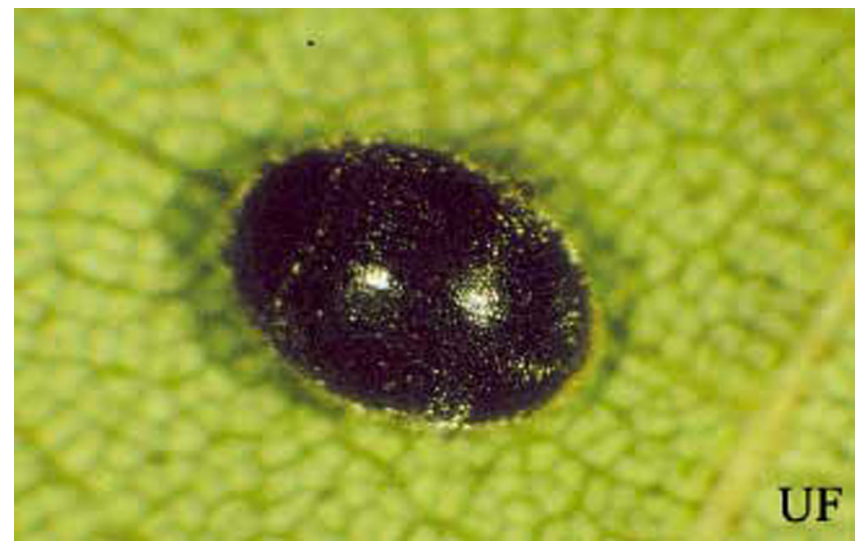

Figure 8. Adult Scymnus sp., a lady beetle. Credits: Russell F. Mizell, University of Florida

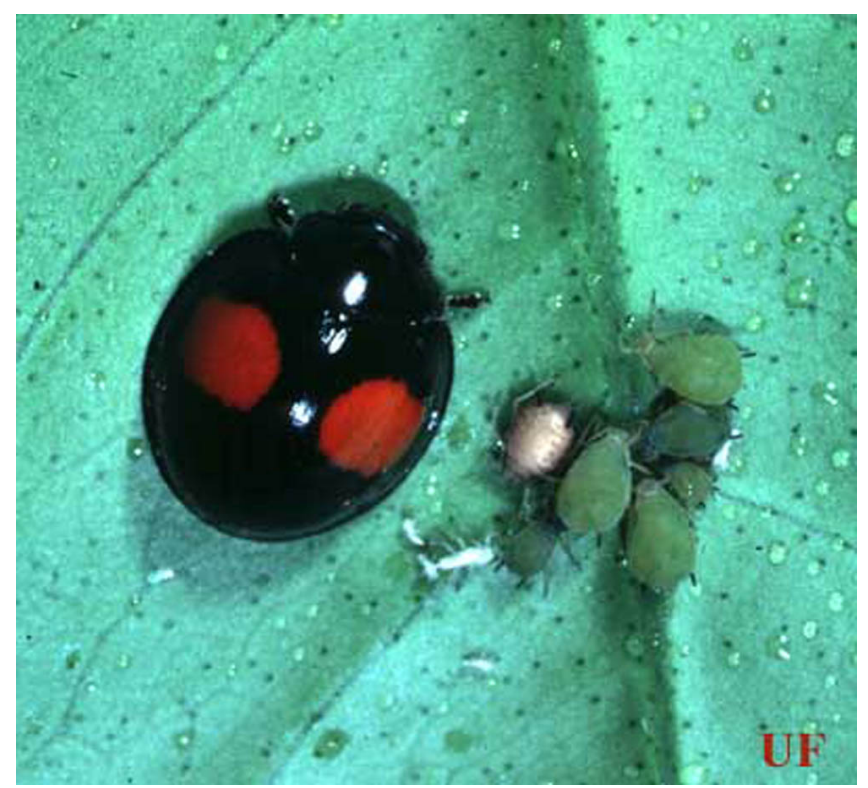

Figure 9. Adult twicestabbed lady beetle, Chilocorus stigma (Walker), (red spots are round). Credits: J.P. Michaud, University of Florida

Rhyzobius lophanthae was introduced to California from Australia in 1892 to control scale insects, and somehow later made its way to Florida (there is no record of an early introduction into Florida). Azya orbigera Mulsant was first discovered in Florida in 1975, and seems to be an immigrant from the Neotropical region (Woodruff and Sailer 1977). Decadomius bahamicus (Casey) was first detected in Florida in 1991, and is an immigrant from the Caribbean or the Bahamas or Bermuda (Bennett and Gordon 1991). Diomus roseicollis Mulsant is another immigrant, from Cuba (Gordon 1976). These 


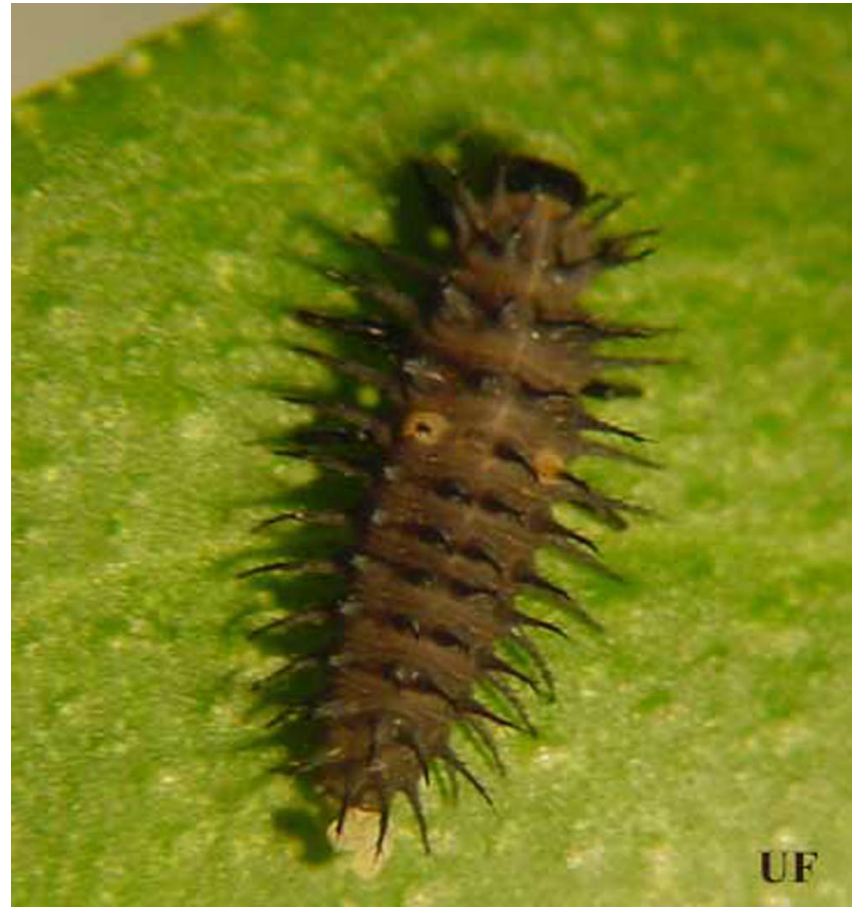

Figure 10. Chilocorus stigma larva. Credits: J.P. Michaud, University of Florida

and other insects that immigrated to Florida are listed and discussed by Frank and McCoy (1992).

\section{(i) Predatory Species - Feeding on Aphids}

Adults and larvae of 12 of the remaining 13 Florida species (the tribe Coccinellini) probably feed primarily on aphids. They include Coccinella novemnotata Herbst, $C$. septempunctata L., Coelophora inaequalis (F.), Coleomegilla maculata DeGeer, Cycloneda munda (Say), Cycloneda sanguinea (L.), Harmonia axyridis Pallas, Harmonia dimidiata (Fabricius), Hippodamia convergens Guérin-Méneville, Mulsantina picta (Randall), Naemia seriata (Melsheimer), Neoharmonia venusta (Melsheimer). Although the 13th species (Olla $v$-nigrum Casey) feeds on some aphid species, it has been shown to be an important predator of psyllids (Michaud 2001).

Four of these, C. septempunctata (from Europe), C. inaequalis (from Australia), H. dimidiata (from China), and $H$. axyridis (from Japan) are not native. The first three were introduced into Florida (Frank and McCoy 1993). The last was introduced by the USDA into Georgia and made its own way to Florida. In some habitats it has built large populations and its adults, in their search for overwintering sites,

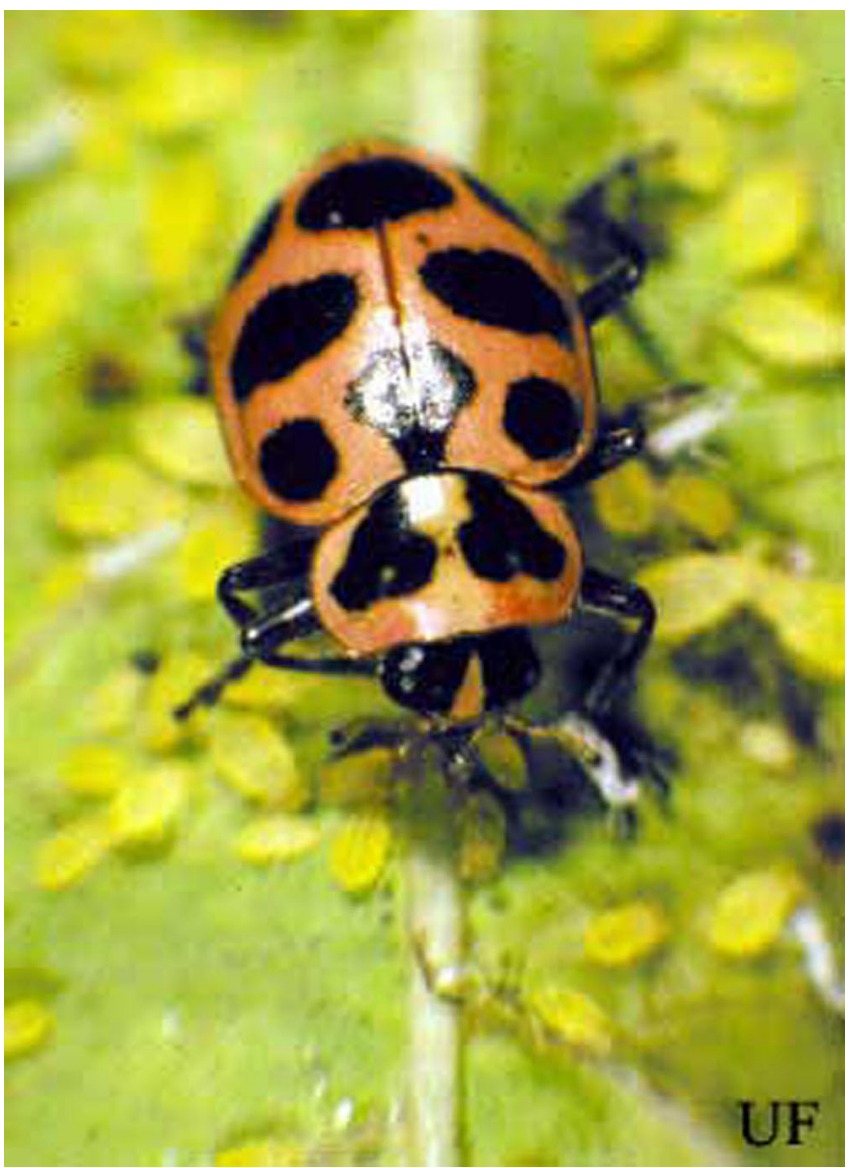

Figure 11. Adult Coleomegilla maculata DeGeer, a lady beetle. Credits: Russell F. Mizell, University of Florida

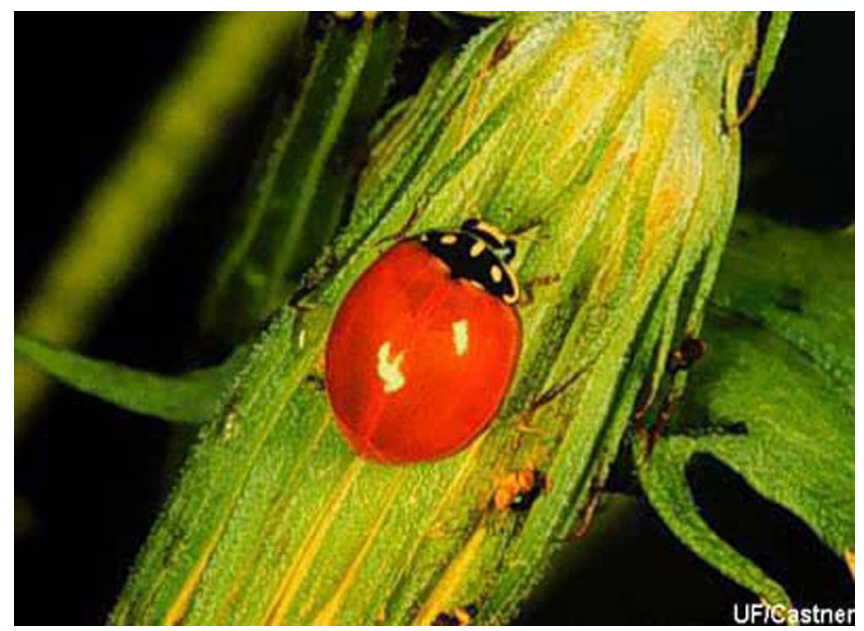

Figure 12. Adult Cycloneda sanguinea (L.), a lady beetle. Credits: James Castner, University of Florida

sometimes are able to enter loosely constructed houses; there they die of desiccation, or they are evicted or destroyed by the householders who accuse them of being pests.

Two of these genera, Coleomegilla and Mulsantina, include adelgids (Adelgidae), which are 


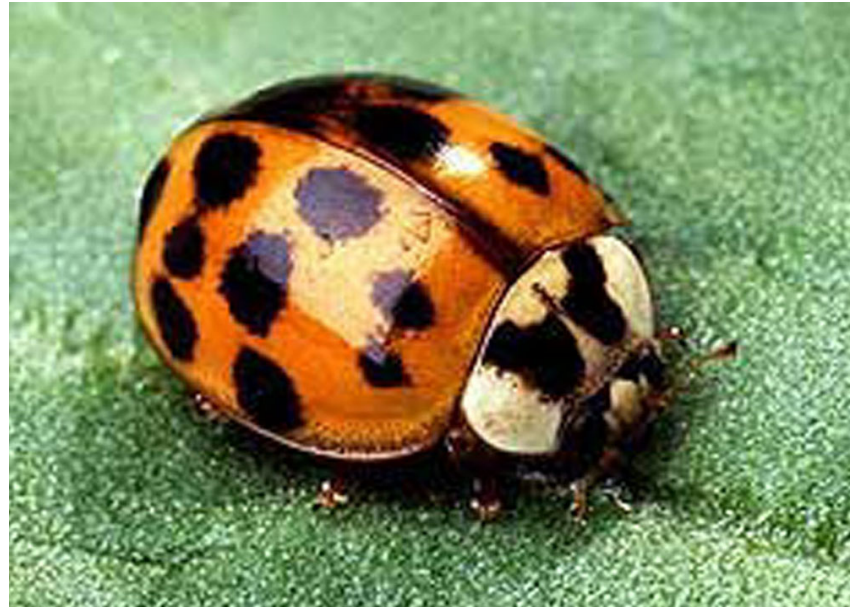

Figure 13. Adult Harmonia axyridis Pallas, the multicolored Asian lady beetle. Credits: Scott Bauer, USDA

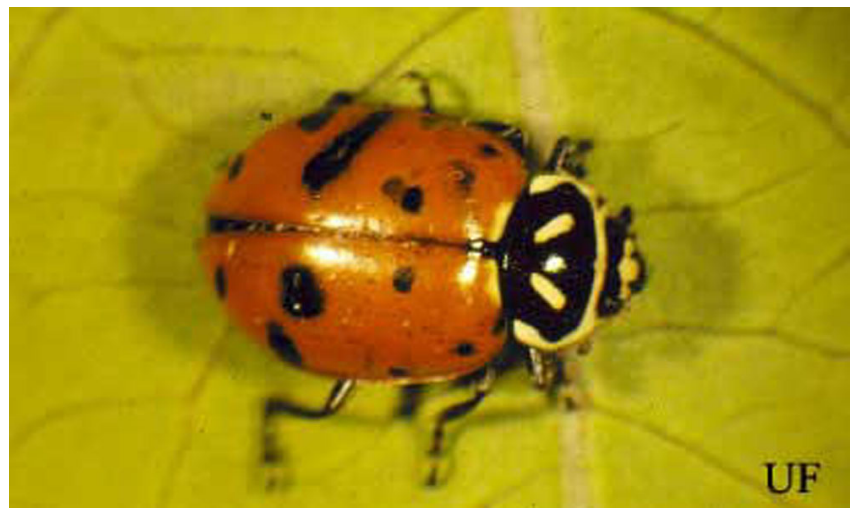

Figure 14. Adult Hippodamia convergens Guérin-Méneville, the convergent lady beetle. Credits: Russell F. Mizell, University of Florida

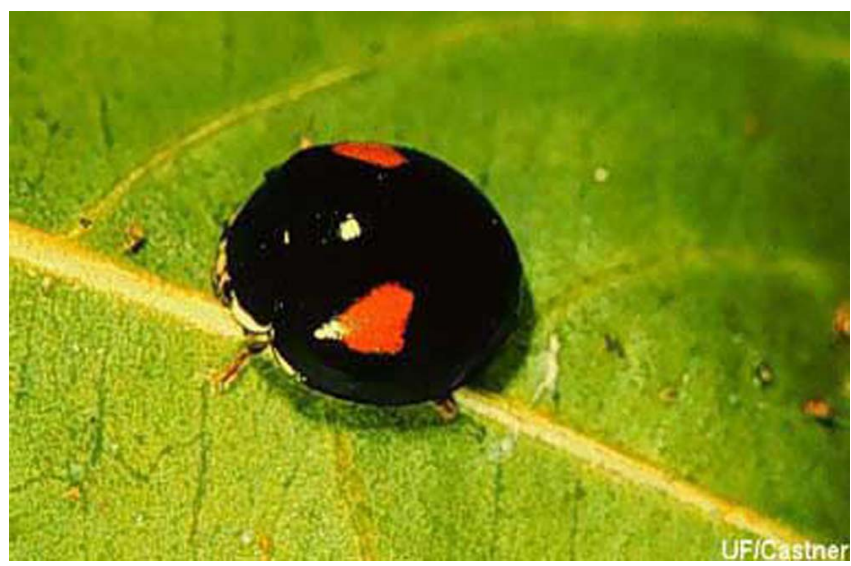

Figure 15. Adult Olla v-nigrum Casey, (red spots are trapezoidal and there is a white edge on the pronotum). Credits: James Castner, University of Florida

closely related to aphids, in their diet. Further, Coleomegilla also includes pollen whereas Mulsantina also includes scale insects in the broad sense.

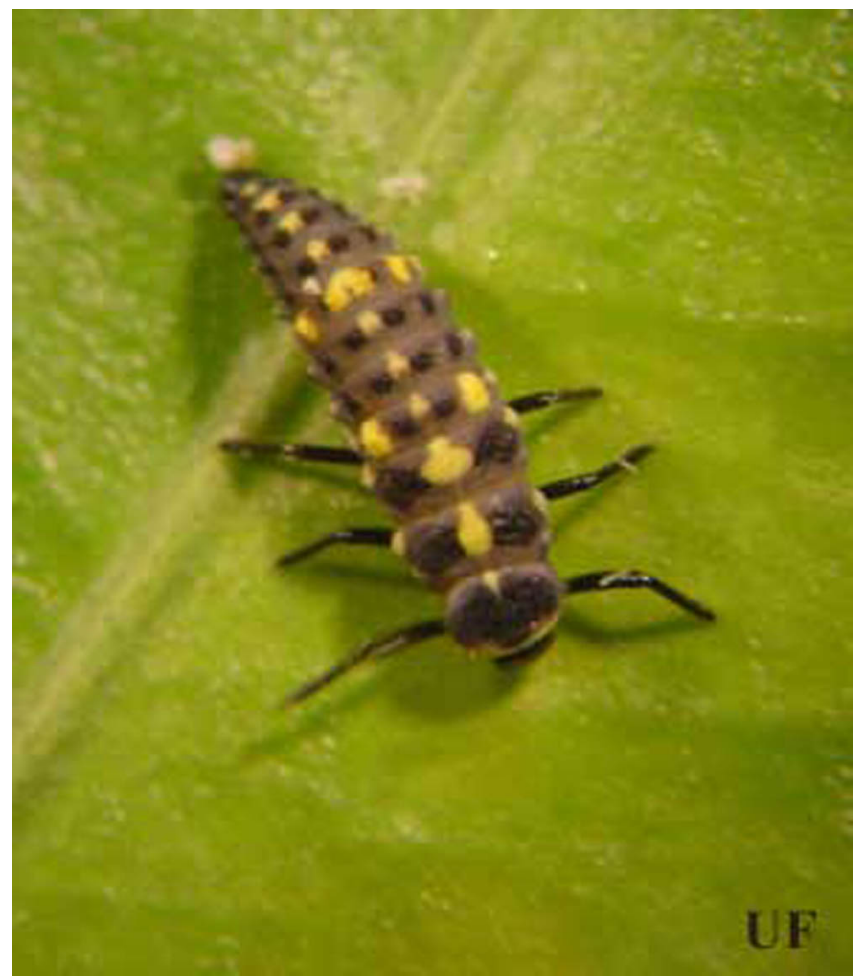

Figure 16. Olla v-nigrum larva. Credits: J.P. Michaud, University of Florida

\section{Alternative Food}

Ladybird larvae and adults may supplement their normal prey in times of scarcity with other types of food. They consume flower nectar, water and honeydew -- the sugary excretion of piercing-sucking insects such as aphids and whiteflies. Many plant species also contain organelles in locations on the plant other than the flower -- termed extrafloral nectaries -- that produce a nutrient-laden secretion. While it was first thought that extrafloral nectaries were used by the plant for excretion, it is well substantiated (Bentley 1977, Pemberton and Lee 1996) that most plants actually use the extrafloral nectaries to attract predators and parasites for protection from their herbivores. Over 2000 species of plants in 64 families have extrafloral nectaries. Plants commonly found in Florida landscapes with extrafloral nectaries are the fruit trees, Prunus spp. (most of the 431 species worldwide have them), passionflower, Passiflora spp.; Ipomoea spp., morningglory; Hibiscus spp., hibiscus; Gossypium hirsutum, cotton; Impatiens sp., impatiens; and Vicia spp., vetch. Extrafloral nectaries may be located on leaf laminae, petioles, rachids, bracts, stipules, pedicels, fruit, etc. Ladybirds often use the secretions 
from extrafloral nectaries in their diet (Pemberton and Vandenberg 1993) and are just some of the many beneficial insects that use extrafloral nectary secretions.

\section{Natural Enemies}

All insects have predators, parasites/parasitoids, and/or pathogens. Ladybirds are not exempt. Larvae of Epilachna borealis and E. varivestis are attacked by a native tachinid fly (Aplomyiopsis epilachnae (Aldrich)) which specializes in the genus Epilachna. Larvae of $E$. varivestis also are attacked by a eulophid wasp (Pediobius foveolatus, see above). This wasp is a parasitoid of other epilachnine ladybirds in India, and was introduced into the USA specifically to control Epilachna varivestis. Another native tachinid fly, Hyalmyodes triangulifer (Loew), is less specialized, attacking larvae not only of Epilachna varivestis, but also of Coleomegilla maculata, several weevils, and a pterophorid moth. Perhaps the best known of the parasitoids of ladybirds is the braconid wasp Perilitus coccinellae (Schrank). It attacks adult ladybirds and to a lesser extent larvae and pupae (Obrycki et al. 1985). It attacks Coccinella septempunctata, Coleomegilla maculata, and several other species. Many other parasitoids and pathogens of ladybirds are not mentioned here for lack of space.

\section{Use of Ladybirds in Biological Control}

Most species of ladybirds are considered beneficial because they are predators of Homoptera or Acarina, many of which are considered to be pests. These predatory ladybirds contribute to the regulation of populations of their prey, and in some situations contribute a high level of regulation. When ladybirds naturally contribute a high level of control of pests, or in combination with other predators and/or parasitoids and diseases contribute a high level of population regulation of pests, people may benefit. That is to say that gardeners, growers and farmers may benefit, at no cost, because they have no or negligible pest problems.

Sometimes, gardeners mistake the ladybird larvae for pests and spray chemical pesticides that kill them (this is much less of a problem with growers and farmers because they have more experience). The result is increased problems from real pests. The answer is a constant educational effort to inform people about ladybirds and what their larvae look like. This effort cannot end, because people knowing nothing about ladybird life cycles are born each minute.

One type of biological control is thus called manipulative biological control (of which a subset is conservation biological control). The objectives are simply to capitalize on the ladybirds (or other beneficial organisms) that already are present, to make conditions as favorable as possible for them (manipulation), and especially to avoid spraying chemicals (insecticides, fungicides, or herbicides) that will harm them (conservation) (see Liu and Stansly 1996).

A second type of biological control is augmentative biological control. This begins with the recognition that ladybirds in a given pest situation are present but too few to do the job required, and buying more from a commercial producer to release to augment those already present. A risk is that if adult ladybirds are released, many of them may fly away. But, if ladybird larvae are released, they have the option of eating the pest with which they are presented, or starving -- they cannot fly away. Obviously, this requires matching the pest to a purchased ladybird species that will eat that pest (see above for species options). The rub here is that the number of purchased ladybirds needed for a given pest situation may not have been worked out in detail -- it demands a huge amount of practical experience to tie down the details for at least hundreds of situations. Documentation of this experience is progressing very slowly.

A third type of biological control is classical or inoculative biological control. Here, some individuals of a ladybird (or other) species that is not already present are released in the hope that they will establish a population and eventually control the pest that is of concern. Classical biological control typically applies to a situation in which a new pest has invaded, and researchers (from a university, the USDA, or a state department of agriculture) import and release a ladybird (or other kind of organism) 
that is believed to control the pest elsewhere.

Typically, the imported ladybird (or other organism) becomes established or does not become established; if it becomes established, it may or may not control the pest in this new situation. Typically, the foregoing things are done under the name of "research," and either are cost-free to gardeners, growers and farmers (especially if done by state or federal departments of agriculture) or, if done by university researchers, then gardeners, growers and farmers are asked to contribute toward a grant that will pay for the cost of importation and research on the biological control agent (but subsequently, after it has become established, there are no further costs). The archetypical example is control of cottonycushion scale of citrus by the introduced ladybird Rodolia cardinalis. Although chemical pesticides of the time were failing to control it, and although it threatened to ruin California's citrus industry, nobody was willing to invest funds in biological control research. Nevertheless, biological control research was "bootlegged" onto other operations by dedicated researchers, was astoundingly successful, and saved California's (and later Florida's) citrus industry from ruin: there was no subsequent need to use chemicals against this pest, thus saving billions of dollars as against a trivial expenditure (about $\$ 1500$ at the time, for foreign travel).

Glasshouses (greenhouses) provide a habitat for plants and pests and biological control agents that differs from outdoor habitats. Typically, culture begins with initiation of a crop of plants that has no pests (or seems to have none). But then, pests somehow show up, and there are no ladybirds (or other organisms) to control them. The situation is very much like that of classical biological control, and ladybirds (and/or other beneficial organisms) released into the greenhouses may control the pests and eliminate need to use chemical pesticides. Here, the question is not about funding new research into a new pest, but into buying the right numbers of ladybirds (or other organisms) of the appropriate species to control a pest that has already been researched. For many such situations, ladybirds (or other organisms) can be purchased from commercial supply houses to control the pest(s). A list of ladybird species available commercially follows below. There is no space in this article to describe how they should be used: that should be done in articles about each individual ladybird species.

\section{Commercial Availability}

The following species list is posted on the California Department of Food and Agriculture's website, which can be accessed to provide information about current suppliers.

- Coleomegilla maculata - a predator of aphids you must buy the native Florida subspecies Coleomegilla maculata fuscilabris because other subspecies are not now permitted to be imported to Florida. Most suppliers do not have this native Florida subspecies, but have instead Coleomegilla maculata lengi (from the eastern USA except Florida) or Coleomegilla maculata strenua (from the southwestern USA).

- Cryptolaemus montrouzieri - a predator of mealybugs - this species occurs in Florida.

- Delphastus pusillus - a predator of whiteflies this species occurs in Florida.

- Harmonia axyridis - a predator of aphids - this species occurs in Florida.

- Hippodamia convergens - a predator of aphids this species occurs in Florida but there still is a potential problem - some suppliers do not rear the beetles but collect overwintering adults from the mountains of eastern California - these overwintering adult beetles (a) may be heavily parasitized and many may die, and (b) may be programmed at the end of the winter to end the hibernation by flying west (which may do you no good if they all take to flight and leave your property).

- Rhyzobius lophanthae - a predator of scale insects - this species occurs in Florida.

- Rhyzobius ventralis - this name is listed in error - it should be called Rhyzobius forestieri - a species that does not occur in Florida.

- Stethorus picipes - a predator of tetranychid mites - this name is listed in error - it should be called Stethorus punctum picipes - a subspecies 
of Stethorus punctum, which is a species that does not occur in Florida.

- Stethorus punctillum - a predator of tetranychid mites - this species does not occur in Florida.

All shipments of living insects into Florida are required to have permits from the Florida Department of Agriculture and Consumer Services, Division of Plant Industry. It is the vendors who are required to obtain the permits for commercial shipments. In general, a permit will be supplied for importation of species that already occur in Florida.

Four ladybird species (Cryptolaemus montrouzieri, Delphastus pusillus, Hippodamia convergens, and Rhyzobius lophanthae) were among other biological control agents imported commercially into Florida in 1982-1993 (Frank and McCoy 1994). More recently, supply houses have been opened in Florida. Four ladybirds (Coleomegilla maculata, Cryptolaemus montrouzieri, Harmonia axyridis, and Hippodamia convergens) have been reared on purely artificial diets, thus promising to reduce labor costs and thus the price of commercially-available ladybirds (Grenier et al. 1994).

Some suppliers will send you good, healthy ladybirds, but others may not. The Association of Natural Biocontrol Producers (ANBP) is dedicated to holding its members to high standards.

\section{Selected References}

Bennett FD, Gordon, RD. 1991. New Florida ladybeetle. Florida Entomologist 74: 598-599.

Bentley BL. 1977. Extrafloral nectaries and protection by pugnacious bodyguards. Annual Review of Ecology and Systematics 8: 407-427.

Dixon AFG. 2000. Insect predator-prey dynamics: Ladybird beetles and biological control. New York: Cambridge Univ Press. ix +257 p.

Frank JH, Kanamitsu K. 1987. Paederus sensu lato (Coleoptera: Staphylinidae): Natural history and medical importance. Journal of Medical Entomology 24: 155-191.
Frank JH, McCoy ED. 1990. Endemics and epidemics of shibboleths and other things causing chaos. Florida Entomologist 73: 1-8.

Frank JH, McCoy ED. 1992. The immigration of insects to Florida with a tabulation of records published since 1970. Florida Entomologist 75: 1-28.

Frank JH, McCoy ED. 1993. The introduction of insects into Florida. Florida Entomologist 76: 1-53.

Frank JH, McCoy ED. 1994. Commercial importation into Florida of invertebrate animals as biological control agents. Florida Entomologist 77: 1-20.

Gordon RD. 1976. The Scymnini (Coleoptera: Coccinellidae) of the United States and Canada: key to genera and revision of Scymnus, Nephus, and Diomus. Bulletin of the Buffalo Society of Natural Sciences 28: 1-362.

Gordon RD. 1985. The Coccinellidae (Coleoptera) of America north of Mexico. Journal of the New York Entomological Society 83: 1-912.

Grenier S, Greany PD, Cohen AS. 1994. Potential for mass release of insect parasitoids and predators through development of artificial culture techniques. p. 181-205 In: Rosen D, Bennett FD, Capinera JL. Pest management in the subtropics. Biological Control - A Florida Perspective. Andover, UK: Intercept.

Hoelmer KA, Osborne LS, Yokomi RK. 1993. Reproduction and feeding behavior of Delphastus pusillus (Coleoptera: Coccinellidae), a predator of Bemisia tabaci (Homoptera: Aleyrodidae). Journal of Economic Entomology 86: 322-329.

Liu TX, Stansly PA. 1996. Toxicological effects of selected insecticides on Nephaspis oculatus (Col., Coccinellidae), a predator of Bemisia argentifolii (Hom., Aleyrodidae). Journal of Applied Entomology 120: 369-373.

Liu TX, Stansly PA, Hoelmer KA, Osborne LS. 1997. Life history of Nephaspis oculatus (Coleoptera: Coccinellidae), a predator of Bemisia argentifolii (Homoptera: Aleyrodidae). Annals of the Entomological Society of America 90: 776-782. 
Michaud JP. 2001. Numerical response of Olla $v$-nigrum (Coleoptera: Coccinellidae) to infestations of Asian citrus psyllid (Hemiptera: Psyllidae) in Florida. Florida Entomologist 18: 608-612.

Michaud JP, McCoy CW, Futch SH. (June 2002). Ladybeetles as biological control agents in citrus. EDIS. http://edis.ifas.ufl.edu/HS138 (10 September 2002).

Nong L, Bennett FD. 1994. Biological control of the Mexican bean beetle. p. 115-122 In: Rosen D, Bennett FD, Capinera JL. Pest management in the subtropics. Biological Control - A Florida Perspective. Andover, UK: Intercept.

Obrycki JJ, Tauber MJ, Tauber CA. 1985. Perilitus coccinellae (Hymenoptera: Braconidae): parasitization and development in relation to host-stage attacked. Annals of the Entomological Society of America 78: 852-854.

Peck SB, Thomas MC. (1998). A distributional checklist of the beetles (Coleoptera) of Florida. Arthropods of Florida and Neighboring Land Areas 16: i-viii, 1-180.

http://www.fsca-dpi.org/Coleoptera/ ColeopteraFrame.htm (2 March 2001).

Pemberton RW, Lee L. 1996. The influence of extrafloral nectaries on parasitism of an insect herbivore. American Journal of Botany 83: 1187-1194.

Pemberton RW, Vandenberg NJ. 1993. Extrafloral nectar feeding by ladybird beetles (Coleoptera; Coccinellidae). Proceedings of the Entomological Society of Washington 95: 139-151.

Sanchez-Arroyo H. (November 1997). Mexican bean beetle, Epilachna varivestis Mulsant. UF/IFAS Featured Creatures.

http://creatures.ifas.ufl.edu/veg/bean/ mexican_bean_beetle.htm (October 2000) or EDIS document http://edis.ifas.ufl.edu/IN141.

Stevens LM, Steinhauer AL, Coulson JR. 1975. Suppression of Mexican bean beetle on soybeans with annual inoculative releases of Pediobius foveolatus. Environmental Entomology 4: 947-948.
Woodruff RE, Sailer RI. 1977. Establishment of the genus Azya in the United States. Florida Department of Agriculture and Consumer Services, Division of Plant Industry, Entomology Circular 230: $1-2$.

[Footnote: The status of Delphastus catalinae (Horn) in Florida (Frank and McCoy 1993) needs further investigation. ] 
Table 1. The 96 species of Coccinellidae known from Florida. Subfamilies are indicated in bold capitals, and tribes. For their author names and distribution by county, see Peck and Thomas (1998).

\begin{tabular}{|c|c|c|c|}
\hline STICHOLOTIDINAE & Nephus (3) & H. binotata & Azyini \\
\hline Microweiseini & N. bivulnerus & H. connectens & Azya (1) \\
\hline Microweisea (3) & N. flavifrons & H. conviva & A. orbigera \\
\hline M. coccidivora & N. intrusus & H. fimbriolata & \\
\hline M. misella & Scymnus (16) & H. inedita & COCCINELLINAE \\
\hline M. ovalis & S. apicanus & H. lateralis & Coccinellini \\
\hline Serangiini & S. brullei & H. lewisi & Coccinella (2) \\
\hline Delphastus (2) & S. caudalis & H. nigrosuturalis & C. novemnotata \\
\hline D. pallidus & S. cervicalis & H. ornatella & C. septempunctata \\
\hline \multirow[t]{2}{*}{ D. pusillus } & S. creperus & H. paludicola & Coelophora (1) \\
\hline & S. fraternus & H. pistillata & C. inaequalis \\
\hline SCYMNINAE & S. indianensis & H. proba & Coleomegilla (1) \\
\hline Scymnillini & S. loewii & H. signata & C. maculata \\
\hline Zagloba (1) & S. louisianae & H. uniformis & Cycloneda (2) \\
\hline Z. bicolor & S. paracanus & Cryptognathini & C. munda \\
\hline Zilus (3) & S. peninsularis & Cryptognatha (1) & C. sanguinea \\
\hline Z. eleutherae & S. rubricaudus & C. nodiceps & Harmonia (2) \\
\hline Z. horni & S. securus & & H. axyridis \\
\hline Z. subtropicus & S. semiruber & CHILOCORINAE & H. dimidiata \\
\hline Stethorini & S. socer & Chilocorini & Hippodamia (1) \\
\hline Stethorus (1) & S. tenebrosus & Axion (1) & H. convergens \\
\hline S. utilis & Hyperaspini & A. tripustulatum & Mulsantina (1) \\
\hline Scymnini & Brachiacantha (7) & Chilocorus (2) & M. picta \\
\hline Cryptolaemus (1) & B. decimpustulata & C. cacti & Naemia (1) \\
\hline C. montrouzieri & B. decora & C. stigma & N. seriata \\
\hline Decadomius (1) & B. dentipes & Curinus (1) & Neoharmonia (1) \\
\hline D. bahamicus & B. floridensis & C. coeruleus & N. venusta \\
\hline Diomus (9) & B. quadripunctata & Exochomus (2) & Olla (1) \\
\hline D. austrinus & B. querceti & E. childreni & O. v-nigrum \\
\hline D. balteatus & B. schwarzi & E. marginipennis & Halyziini \\
\hline D. bigemmeus & Hyperaspidius (5) & & Psyllobora (2) \\
\hline D. debilis & H. flavocephalus & COCCIDULINAE & P. nana \\
\hline D. floridanus & H. militaris & Coccidulini & P. parvinotata \\
\hline D. humilis & H. nubilatus & Rhyzobius (1) & \\
\hline D. roseicollis & H. transfugatus & R. lophanthae & EPILACHNINAE \\
\hline D. terminatus & H. venustulus & Noviini & Epilachnini \\
\hline D. xanthaspis & Hyperaspis (16) & Rodolia (1) & Epilachna (2) \\
\hline Nephaspis (1) & H. bigeminata & R. cardinalis & E. borealis \\
\hline N. oculata & H. binaria & & E. varivestis \\
\hline
\end{tabular}

